\title{
Dormancy Breaking and the Influence of Temperature, Substrate and Light on Germination of Colubrina glandulosa Seeds
}

\author{
Yana Souza Lopes ${ }^{1}$ (D) \\ Lúcia de Fatima de Carvalho Chaves ${ }^{1}$ \\ Fernanda Freitas Souza ${ }^{2}$ \\ Jacqueline Wanessa de Lima Pereira ${ }^{3}$ \\ Rejane Rodrigues da Costa e Carvalho ${ }^{3}$ \\ José Luiz Sandes de Carvalho Filho ${ }^{3}$
}

\begin{abstract}
This study aimed to define a methodology that, when combined with temperature, can overcome the dormancy and also to determine the adequate substrate and light conditions for germination of Colubrina glandulosa Perkins, contributing to seed analysis and restoration projects. In the experiment of dormancy and temperature, seeds were immersed in sulfuric acid for $30,60,90,120$ and 150 minutes and set to germinate at temperatures of $20-30^{\circ} \mathrm{C}, 25^{\circ} \mathrm{C}$ and $30^{\circ} \mathrm{C}$. The used substrates were sand, vermiculite, Tropstrato substrate, coconut powder, blotting paper and paper towel. As for the light supplied, the seeds were subjected to four luminosity regimes: white light, far-red light, red light and light absence. Temperatures of $20-30{ }^{\circ} \mathrm{C}$ and $30{ }^{\circ} \mathrm{C}$ achieved better results, with exposure in sulfuric acid for 120 and 150 minutes. The substrates sand and vermiculite were the most suitable. The species germinated in all light regimes treatments used.
\end{abstract}

Keywords: seed dormancy, seed germination, ecophysiology, restoration ecology.

\section{INTRODUCTION AND OBJECTIVES}

The subjugation of global ecosystems by human beings has increased the rates of extinction, threatening not just the well-being of people, but also affecting the natural ecosystems services (Johnson et al., 2017). In Brazil, several forest ecosystems are degraded as a result from the anthropic activities. For this reason, restoring and expanding these environments turned into an important task, which is beneficial for biodiversity, climate, water quality, as well as for providing other ecosystem services (Bright et al., 2017; Houghton \& Nassikas, 2018).

Due to the forest restoration expansion and the increasing demand for seedlings production, studies focused on the ecophysiology of seed germination in native forest species are on the rise due to their environmental and economic potential use. Moreover, it contributes to the rational exploitation and use of these species (Rodrigues Filho et al., 2019; Santos et al., 2019; Oliveira et al., 2020a).

Among the species that may be used on forest restoration is Colubrina glandulosa Perkins (Rhamnaceae). This native species is a pioneer that occurs from the eastern coast of Brazil to Paraguay and Peru. It grows quickly, facilitating the establishment of other species that require shading areas, thus being important for the ecological succession. In addition, it has a huge using potential in carbon compensation projects and its seeds present physical dormancy, which allows them to remain inactive in the seed bank, an important strategy for the population dynamics (Silva et al., 2015; Marcos Filho, 2015; Camara et al., 2017; Morais Júnior et al., 2018; Melo Júnior et al., 2018). However, there is no methodology available in the Rules for Seed Analysis (Brasil, 2009) that determines procedures to be applied for germination tests in this species (Melo Júnior et al., 2018).

\footnotetext{
${ }^{1}$ Universidade Federal Rural de Pernambuco (UFRPE), Departamento de Ciência Florestal, Recife, PE, Brasil

${ }^{2}$ Universidade Federal de Pernambuco (UFPE), Centro de Biociências, Recife, PE, Brasil

${ }^{3}$ Universidade Federal Rural de Pernambuco (UFRPE), Departamento de Agronomia, Recife, PE, Brasil
} 
Although seed dormancy works as an efficient mechanism to ensure the species survival, it also may be a barrier for the propagating plants with economic interest (Brito et al., 2016). Physical dormancy is common in forest species, and different methods can be used in order to overcome it, such as the immersion in hot water and the mechanical or acidic scarification (Guedes et al., 2013; Barbedo \& Santos Júnior, 2018).

The temperature is one of the main factors conditioning the seeds germination process (Oliveira et al., 2020b). It affects the water absorption rate and the biochemical reactions that control germination, influencing both the germination percentage and its speed index. In general, species demonstrate physiological variations when exposed to different temperatures, and for this very reason evaluating this germination aspect is important (Marcos Filho et al., 2015; Araújo et al., 2016).

Substrates may be chosen when considering the seed size, moisture requirement, light sensitivity and the ease in counting and evaluating the seedlings (Abreu et al., 2017). In the laboratory tests, the most used substrates are paper towel, blotting paper, vermiculite and sand, with the last two as the most indicated since they present lesser infestation by microorganisms (Araújo et al., 2016).

Seed germination may be also influenced by light, which can promote or inhibit it. Species can be classified in three ways according to their light response: those that require light to germinate (positive photoblastic); those that require darkness to germinate (negative photoblastic); and those that have a large percentage of their seeds neutral to light (neutral photoblastic) (Baskin \& Baskin, 2014; Flores et al., 2016).

The aim of this study was to determine a methodology that, associated to the use of temperature, overcomes dormancy, never before evaluated in other studies with this species, as well as to establish ideal conditions of substrate and light for the germination of Colubrina glandulosa Perkins seeds. The results will contribute to determine adequate procedures for seedlings production to be used in projects of forest recovery, urban afforestation and restoration.

\section{MATERIALS AND METHODS}

Colubrina glandulosa Perkins fruits were collected in two different trees located in Carpina, Pernambuco ( $7^{\circ} 50^{\prime} 42.4^{\prime \prime} \mathrm{S}$, $\left.35^{\circ} 14^{\prime} 50.1^{\prime \prime} \mathrm{W}\right)$. The climate of the region is classified as As' according to the Köppen classification. The fruits were manually collected and then benefited, identified and stored inside plastic bags under room temperature conditions. Botanical fertile material was also collected for confirming the identification of Colubrina glandulosa Perkins.

Moisture content of Colubrina glandulosa seeds was performed by using the oven method at $105^{\circ} \mathrm{C}$ for 24 hours.
Four replicates composed by $2 \mathrm{~g}$ of seeds each were placed in previously weighed aluminum capsules $(6 \mathrm{~cm}$ of diameter $\mathrm{x} 4 \mathrm{~cm}$ of height). After the elapsed time, the samples were removed from the oven and placed in a desiccator for ten minutes and then weighted on an analytical balance with accuracy of $0.0001 \mathrm{~g}$. The resulting water content was expressed in percentage, as suggested by the Rules for Seeds Analysis (Brasil, 2009) and the classification of seeds according to the moisture content identified, as described by Chin et al., (1989).

C. glandulosa seeds were immersed in concentrated sulfuric acid (H2SO4) under five different times: 30, 60, 90, 120 and 150 minutes. After that, they were disinfected with $5 \%$ sodium hypochlorite for five minutes, washed with distilled water and sown in transparent plastic boxes containing vermiculite substrate, with four replicates of 25 seeds each. The plastic boxes were then kept in a germinating chamber, Biochemical Oxygen Demand (B.O.D.) type, at three different temperatures: $25^{\circ} \mathrm{C}, 30^{\circ} \mathrm{C}$ and $20-30{ }^{\circ} \mathrm{C}$, as suggested by Albuquerque et al. (1998).

As for the substrate evaluation, seeds were subjected to the pre-germinative treatment of immersion in concentrated $\mathrm{H} 2 \mathrm{SO} 4$ for 120 minutes. Substrates used in the sowing were the following: sand (T1), vermiculite (T2), coconut powder (T3), Tropstrato substrate (T4), blotting paper (T5) and paper towel (T6), with this last one arranged in rolls. The substrates were previously autoclaved for two hours at $120{ }^{\circ} \mathrm{C}$, moistened with a $0.2 \%$ nystatin solution and only then were placed in the plastic boxes (dimensions $11 \times 11 \times 3 \mathrm{~cm}$ ) with four replicates of 25 seeds in each treatment. Subsequently, these boxes were stored in the B.O.D. set with an alternating temperature of $20-30^{\circ} \mathrm{C}$ and under continuous light.

In relation to light quality, the seeds were subjected to the same pre-germinative treatment of immersion in sulfuric acid for 120 minutes. The blotting paper, with four replicates of 25 seeds each, was used for sowing, and seeds were kept in a B.O.D.-type germinating chamber. For evaluating the germinative behavior of seeds, four different light conditions were used: white light (WL), far-red light (FRL), red light (RL) and no light (NL), as suggested by Silva and Matos (1998).

The evaluation of the germinated seeds occurred until the 20th day after sowing, using as germination criterion the hypocotyl appearance and the cotyledons emergence, as well as the early epicotyl emission.

Evaluated parameters were the following: germination (G), expressed in percentage; germination speed index (GSI), as suggested by Maguire (1962); first germination count (FC), corresponding to the percentage of seeds germinated in the period of the first normal seedlings; mean germination time (MGT), according to Silva and Nakagawa (1995); the shoot 
and root lengths of the seedlings, by using a ruler graduated in centimeters, and the dry matters of their shoot and root as well. Evaluation of the shoot and root dry matters of the seedlings occurred after keeping them in a forced-ventilation oven at $80^{\circ} \mathrm{C}$ for 24 fours, and after this period, the seedlings were kept in a desiccator for ten minutes and then weighted on an analytical balance with accuracy of $0.0001 \mathrm{~g}$, as suggested by Nakagawa (1999).

The data were analyzed by using SISVAR (DEX/UFLA), version 5.3. The analysis of variances (ANOVA) was performed for all tests. Regarding the dormancy and temperature, a factorial design of $3 \times 5$ (temperatures $x$ time of immersion in sulfuric acid) was used. The Scott-Knott test at $5 \%$ of probability was applied to evaluate significant differences in the temperature. As for the quantitative effects, a polynomial regression was performed, testing the linear and quadratic models, selecting the significant with higher $\mathrm{R}^{2}$. For the effects of substrate and light, the Scott-Knott test at $5 \%$ of probability was also performed.

\section{RESULTS AND DISCUSSION}

For this research, the moisture content of C. glandulosa seeds was $12.79 \%$, classifying these seeds as orthodoxies. It demonstrates the species tolerance to desiccation during its development. Seeds may be also stored in dry and cold places to be conserved (Chin et al., 1989).

The water content also is related to the longevity, as seeds that have better protection against damage occurring in dry conditions survive longer. Understanding seed longevity and storage help in developing better tools for management and conservation of the species (Walters, 2015).

\subsection{Influence of dormancy and temperature on germination}

Germination, germination speed index, first germination count and shoot dry matter did not have significant interactions between the immersion time in sulfuric acid and the three temperatures for C. glandulosa seeds.

For germination, there was no significant difference between the temperatures. On the other hand, the germination speed index, first germination count and shoot dry matter all had signifcant differences for temperature (Table 1). Seeds kept at $20-30{ }^{\circ} \mathrm{C}$ and $30{ }^{\circ} \mathrm{C}$ demonstrated higher results regarding their germination speed index. The occurrence of germination at both constant and alternating temperature demonstrates adaptations of Colubrina glandulosa for temperature variations (Medeiros, 2019). The alternating and high temperatures probably stimulated the seeds, promoting a faster germination process.
Table 1. Germination Speed Index (GSI), First Germination Count (FGC) and Shoot Dry Matter (SDM) of Colubrina glandulosa seeds subjected to different temperatures.

\begin{tabular}{ccccccccc} 
& \multicolumn{7}{c}{ Temperature } \\
\cline { 2 - 8 } Variables & \multicolumn{7}{c}{$\mathbf{2 0 - 3 0}{ }^{\circ} \mathrm{C}$} & \multicolumn{2}{c}{$25{ }^{\circ} \mathrm{C}$} & $30{ }^{\circ} \mathrm{C}$ & $\mathrm{CV} \%$ \\
\hline GSI & 1.491 & $\mathrm{~A}$ & 1.271 & $\mathrm{~B}$ & 1.422 & $\mathrm{~A}$ & 17.32 \\
FGC & 43.8 & $\mathrm{~A}$ & 37.4 & $\mathrm{~B}$ & 36.2 & $\mathrm{~B}$ & 21.40 \\
\hline SDM & 0.045 & $\mathrm{~B}$ & 0.055 & $\mathrm{~A}$ & 0.063 & $\mathrm{~A}$ & 33.25 \\
\hline
\end{tabular}

Means followed by the same letter in the row do not differ from each other by the Scott-Knott test at 5\% probability.

There are species that germinate better at alternating temperature, and this behavior may be associated to dormant seeds. However, there is no comprehension of the alternating temperatures effects on seeds, but probably this thermal variation promotes a change in the germination promoters/ inhibitors balance (Marcos Filho, 2015).

According to Brancalion et al. (2010), the optimal temperature for germination is related to seed physiological adaptations, besides of the biome where the seeds were produced. Ecological characterization, as the successional group, may influence on the determination of the optimal temperature for the germinative process. For germination of Colubrina glandulosa Perkins seeds, Albuquerque et al. (1998) also recommended the temperatures of $25^{\circ} \mathrm{C}, 30^{\circ} \mathrm{C}$ and $20-30{ }^{\circ} \mathrm{C}$.

Regarding the first germination count, the alternating temperature had the highest percentage, with $43.8 \%$. On the other hand, the shoot dry matter of the seedlings kept at $25^{\circ} \mathrm{C}$ and $30^{\circ} \mathrm{C}$ produced higher results (Table 1 ).

In relation to the immersion time in sulfuric acid, the percentage of germinated seeds were higher in 120 and 150 minutes. Results illustrated by Figure 1A demonstrate an increasing germination of $C$. glandulosa seeds as the permanence time in sulfuric acid grows. Speed germination index also reached higher results in the longer periods of seeds immersion in $\mathrm{H}_{2} \mathrm{SO}_{4}$ (Figure 1B).

The increasing germination of C. glandulosa seeds as the immersion time in sulfuric acid increased demonstrates that, for this species, dormancy overcoming is not only related to the contact of the substance with the seed coat, but to the contact period between seeds and acid. There was also an increase in the germination speed index with the increasing seed immersion time in sulfuric acid. Garcia et al. (2009) reported that sulfuric acid accelerates the germination speed of C. glandulosa seeds. 
A

B
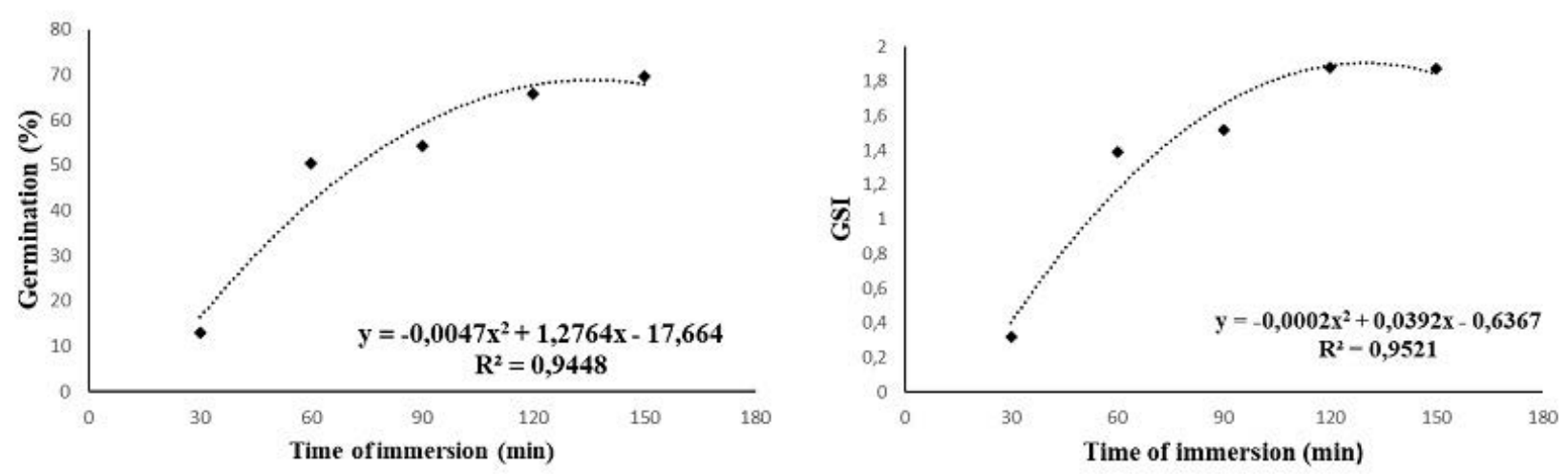

$\mathrm{C}$

D
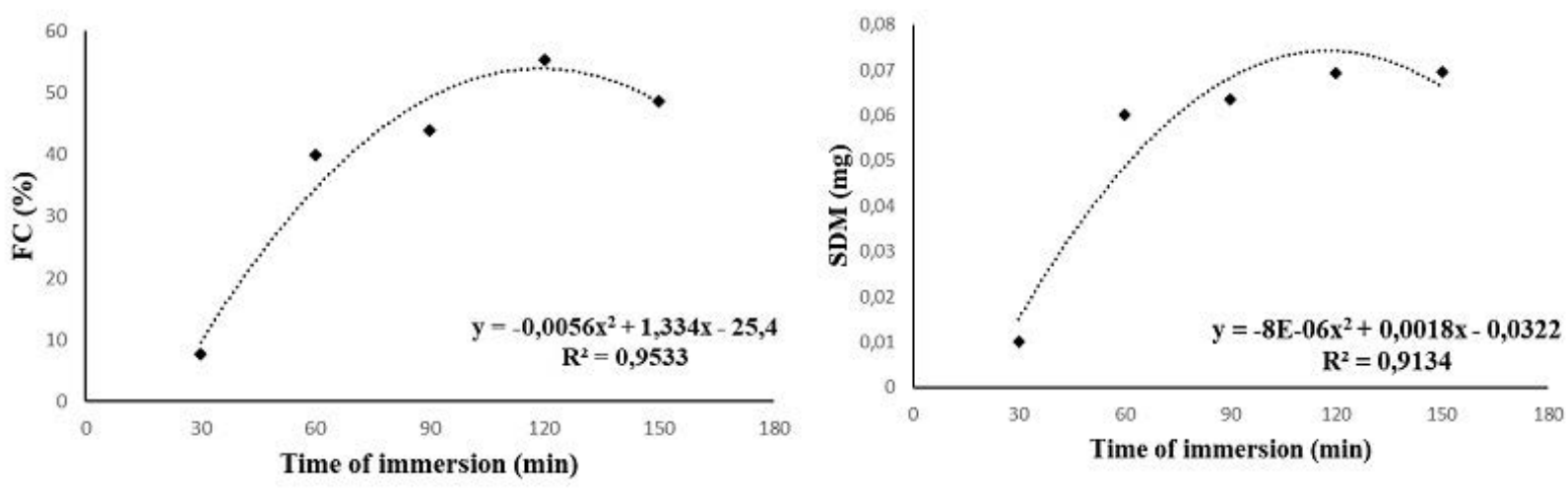

Figure 1. A- Germination; B- germination speed index (GSI); C- first germination count (FGC); and D- shoot dry matter (SDM) of Colubrina glandulosa Perkins seedlings subjected to different immersion times in sulfuric acid $\left(\mathrm{H}_{2} \mathrm{SO}_{4}\right)$.

Sulfuric acid causes a corrosive effect on the seed coat, changing the membrane permeability and allowing the entrance of water, an essential factor for starting the germination process (Dousseau et al., 2007). In addition, according to Smychniuk et al. (2020), specialized anatomical structures (water gaps) in seeds with physical dormancy, may allow the water entrance to begin the imbibition.

The percentage of first germination count was higher in the treatment of 120 minutes (Figure 1C). As for shoot dry matter of C. glandulosa seedlings, its content increased as the immersion time in sulfuric acid was longer; however, there was stabilization between 120 and 150 minutes (Figure 1D).

There was an interaction between temperature and immersion time in sulfuric acid for the mean germination time, shoot length, root length and root dry matter. In general, the germination of C. glandulosa seeds were slower during the 30 minutes of exposition to acid, and took longer at $30^{\circ} \mathrm{C}$.
For the mean germination time (Table 2), there were no differences between treatments; only the immersion of seeds for 30 minutes of $\mathrm{H}_{2} \mathrm{SO}_{4}$ at $30^{\circ} \mathrm{C}$ had statistical difference, with a slower seed germination. Satisfactory results of GSI and MGT were found in 120 minutes of immersion in sulfuric acid at $20-30^{\circ} \mathrm{C}$, indicating the efficiency of this treatment.

In relation to the shoot length of $C$. glandulosa seedlings, higher results were observed at $30{ }^{\circ} \mathrm{C}$ by immersing the seeds in acid for 90 minutes, as well as for 60 minutes at the same temperature (Table 2). Results found by Alves et al. (2006) reported higher growth in Zizyphus joazeiro Mart with 95 minutes of seeds immersion in acid. In this study, exposition for more than 120 minutes compromised the shoot development.

Considering the root length, the combination that produced the highest result was the immersion in acid for 90 minutes at $30^{\circ} \mathrm{C}$ (Table 2). The exposition times of 30, 60, 120 and 150 minutes did not present any statistical differences between the temperatures. 
Table 2. Means from the germination time (MGT), shoot length (SL), root length (RL) and root dry matter (RDM) of Colubrina glandulosa Perkins seeds under different temperatures and subjected to five sulfuric acid immersion times.

\begin{tabular}{|c|c|c|c|}
\hline \multirow[t]{2}{*}{ Time in $\mathrm{H}_{2} \mathrm{SO}_{4}$} & $20-30{ }^{\circ} \mathrm{C}$ & $25^{\circ} \mathrm{C}$ & $30{ }^{\circ} \mathrm{C}$ \\
\hline & \multicolumn{3}{|c|}{ Mean Germination Time (days) } \\
\hline $30^{\prime}$ & $14.2 \mathrm{~B}$ & $11.9 \mathrm{~B}$ & $20.08 \mathrm{~A}$ \\
\hline $60^{\prime}$ & $11.3 \mathrm{~A}$ & $10.5 \mathrm{~A}$ & $11.2 \mathrm{~A}$ \\
\hline 90 ' & $8.7 \mathrm{~A}$ & $13.2 \mathrm{~A}$ & $9.9 \mathrm{~A}$ \\
\hline $120^{\prime}$ & $8.5 \mathrm{~A}$ & $11.9 \mathrm{~A}$ & $9.1 \mathrm{~A}$ \\
\hline \multirow[t]{2}{*}{$150^{\prime}$} & $10.1 \mathrm{~A}$ & $12.2 \mathrm{~A}$ & $9.9 \mathrm{~A}$ \\
\hline & \multicolumn{3}{|c|}{ Shoot length (cm) } \\
\hline $30^{\prime}$ & $2.0625 \mathrm{~A}$ & $1.7667 \mathrm{~A}$ & $1.7000 \mathrm{~A}$ \\
\hline $60^{\prime}$ & $2.7929 \mathrm{~B}$ & $2.0232 \mathrm{C}$ & $4.3389 \mathrm{~A}$ \\
\hline $90^{\prime}$ & $3.1344 \mathrm{~B}$ & $1.8069 \mathrm{C}$ & $4.5323 \mathrm{~A}$ \\
\hline $120^{\prime}$ & $3.2869 \mathrm{~A}$ & $2.0246 \mathrm{~B}$ & $2.0309 \mathrm{~B}$ \\
\hline \multirow[t]{2}{*}{$150^{\prime}$} & $2.7902 \mathrm{~A}$ & $1.9413 \mathrm{~B}$ & $1.6386 \mathrm{~B}$ \\
\hline & \multicolumn{3}{|c|}{ Root length (cm) } \\
\hline $30^{\prime}$ & $1.6387 \mathrm{~A}$ & $1.6229 \mathrm{~A}$ & $1.3833 \mathrm{~A}$ \\
\hline $60^{\prime}$ & $2.1832 \mathrm{~A}$ & $2.1111 \mathrm{~A}$ & $2.1516 \mathrm{~A}$ \\
\hline $90^{\prime}$ & $2.2420 \mathrm{~B}$ & $2.0121 \mathrm{~B}$ & $3.0556 \mathrm{~A}$ \\
\hline $120^{\prime}$ & $1.9461 \mathrm{~A}$ & $1.8122 \mathrm{~A}$ & $2.1240 \mathrm{~A}$ \\
\hline \multirow[t]{2}{*}{$150^{\prime}$} & $1.7155 \mathrm{~A}$ & $1.9487 \mathrm{~A}$ & $1.8673 \mathrm{~A}$ \\
\hline & \multicolumn{3}{|c|}{ Root dry matter (mg) } \\
\hline $30^{\prime}$ & $0.0027 \mathrm{~A}$ & $0.0020 \mathrm{~A}$ & $0.0025 \mathrm{~A}$ \\
\hline $60^{\prime}$ & $0.0112 \mathrm{~B}$ & $0.0122 \mathrm{~B}$ & $0.0245 \mathrm{~A}$ \\
\hline $90^{\prime}$ & $0.0097 \mathrm{~B}$ & $0.0127 \mathrm{~B}$ & $0.0370 \mathrm{~A}$ \\
\hline $120^{\prime}$ & $0.0192 \mathrm{~A}$ & $0.0172 \mathrm{~A}$ & $0.0210 \mathrm{~A}$ \\
\hline $150^{\prime}$ & $0.0207 \mathrm{~A}$ & $0.0192 \mathrm{~A}$ & $0.0167 \mathrm{~A}$ \\
\hline
\end{tabular}

Means followed by the same letter in the row do not differ from each other by the Scott-Knott test at 5\% probability. CV(\%): MGT=29.43; $\mathrm{SL}=14.89 ; \mathrm{RL}=13.58$ and $\mathrm{RDM}=36.00$.

In relation to the root dry matter of the seedlings, higher results were attained by using 60 and 90 minutes of acid immersion at $30^{\circ} \mathrm{C}$, as Table 1 indicates. Melo Júnior et al. (2018), during their study, found dry matter content to be higher in 60 minutes of immersion in $\mathrm{H}_{2} \mathrm{SO}_{4}$ for the same species. In their research, the authors suggested, for the germination of seeds, the time of 60 minutes in sulfuric acid.

Regression analysis did not present any significant differences at $25^{\circ} \mathrm{C}$ for MGT. However, at $30^{\circ} \mathrm{C}$ and $20-30{ }^{\circ} \mathrm{C}$ a shorter mean germination time was observed in seeds immersed for 120 minutes in sulfuric acid (Figure 2A). Thus, it is possible noticing that the mean germination time decreases as the exposition time to the acid increases. These results differ from what was found by Carvalheiro et al. (2007) and Melo Júnior et al. (2018), who reported an increased mean germination time of C. glandulosa seeds germination as the exposition time in $\mathrm{H}_{2} \mathrm{SO}_{4}$ also increased. These differences may be explained due to some reasons, such as the environmental factors, genetic factors and nutritional status (Müller et al., 2016).

In relation to the analysis of immersion time in acid at the different temperatures for shoot length (Figure 2B), it is possible noticing that at $20-30{ }^{\circ} \mathrm{C}$ the exponential growth occurred as 
the immersion time increased until 120 minutes, and after that there was a short growth reduction in the last time. At $30^{\circ} \mathrm{C}$, it was possible observing the shoot growth of Colubrina glandulosa seedlings until the time of 90 minutes, and then there was a decline in the time of 120 minutes. There were no significative differences between the treatments for shoot length of seedlings at $25^{\circ} \mathrm{C}$.

For root length, there was no significant difference between immersion times at $25^{\circ} \mathrm{C}$. At $20-30^{\circ} \mathrm{C}$, the root length grew until 90 minutes, having a decline in the other times, as illustrated in Figure 2C. The same behavior was observed at $30{ }^{\circ} \mathrm{C}$, but this temperature demonstrated higher variance between results for root length in the different immersion times in sulfuric acid. According to Rorato et al. (2018), plants with well-developed root system have better conditions to settle in the field, promoting greater survival, maintenance ease and greater nutrient and water absorption.

The regression analysis (Figure 2D) demonstrated that at $20-30^{\circ} \mathrm{C}$ and $25^{\circ} \mathrm{C}$ there was linear growth of the seedlings dry matter content as the immersion time increased, reaching higher results at 120 and 150 minutes.
On the other hand, at $30^{\circ} \mathrm{C}$, it is possible observing the root dry matter growth until 90 minutes, the highest result, followed by a seedlings growth reduction in 120 and 150 minutes. It is possible inferring that $C$. glandulosa seeds generally need a minimum of 90 minutes of immersion in sulfuric acid in order to obtain satisfactory contents of root dry matter.

The results presented here in this research confirm dormancy caused by the impermeability of seed coat in Colubrina glandulosa. Thus, the efficiency of sulfuric acid in overcoming dormancy is proven by being responsible for the appearance of cracks around the hilar slit and porosity of the integument, allowing water absorption and, consequently, the germination.

Chemical scarification with sulfuric acid cannot be used for all the seed species, because there are different dormancy levels that need to be identified in order to determine a more adequate immersion time for promoting higher germination results (Guedes et al., 2013). In the case of Colubrina glandulosa, using sulfuric acid is necessary because its seeds are too small and other methods, such as the mechanical scarification of the seed coat, are not practical (Brancalion et al., 2011).

A
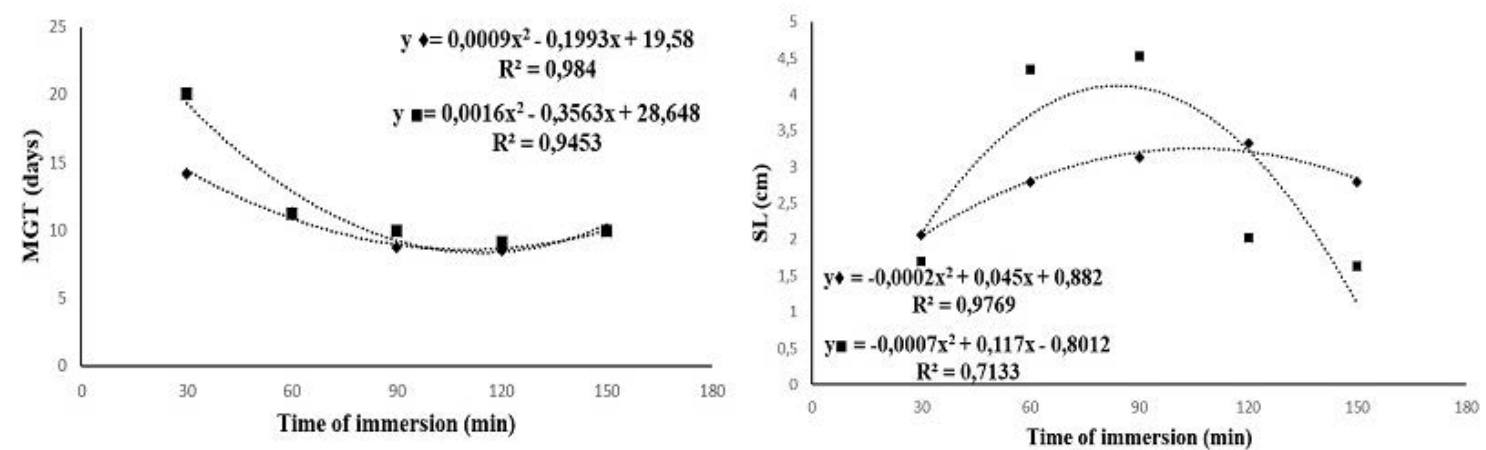

$\mathrm{C}$
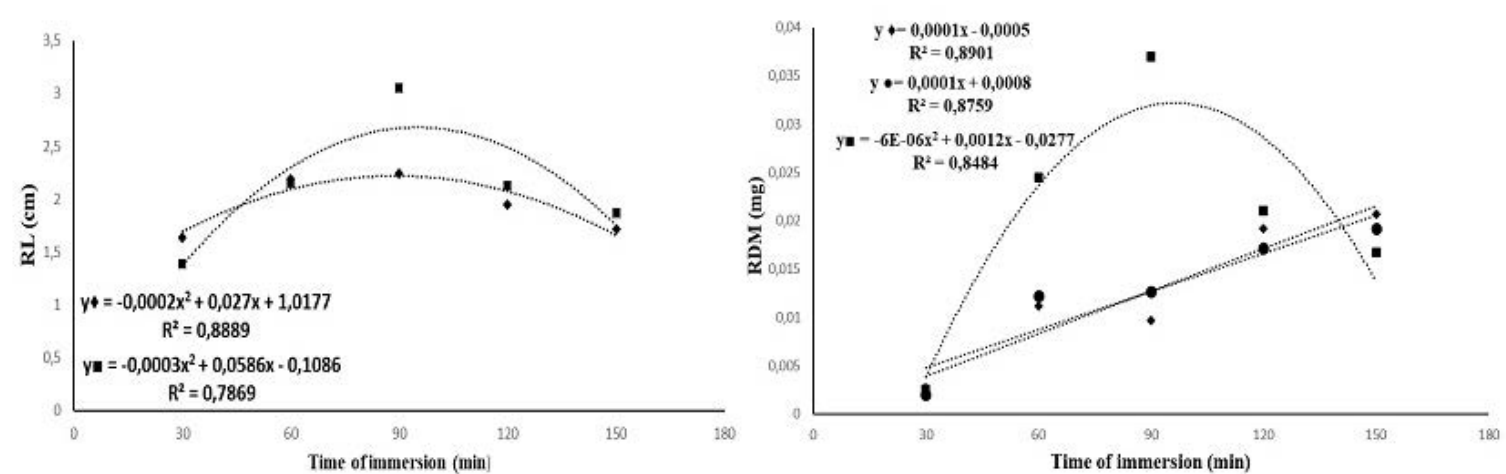

Figure 2. A- Mean germination time (MGT); B- shoot length (SL); C- root length (RL) and D- root dry matter (RDM) of Colubrina glandulosa Perkins under different immersion times in sulfuric acid at the temperatures of $20-30{ }^{\circ} \mathrm{C}(\bullet), 25^{\circ} \mathrm{C}(\bullet)$ and $30^{\circ} \mathrm{C}(\boldsymbol{\bullet})$. 


\subsection{Influence of the substrate on germination}

Sand (T1) and vermiculite (T2) promoted higher germination percentages for seeds (Figure 3A), with no statistical differences between both. The germination percentage is a satisfactory index to evaluate the ability of a species in occupying a natural habitat as a rapid germination strategy allows establishment in the environment as quickly as possible, taking advantage of favorable environmental conditions (Melo et al., 2018). Seeds sowed on coconut powder (T3) had lower results, differing from all the other treatments. The low germination in coconut powder may have occurred because of the high fungi intensity in this treatment, even with the sterilization of substrate, which probably influenced the seed germination and the development of seedlings.

The first germination count, in vermiculite (T2), found a higher percentage, which differed this treatment from the others. It probably happened because vermiculite has low density, porosity and water-holding capacity (Martins et al., 2009).
Sand (T1), Tropstrato substrate (T4), blotting paper (T5) and paper towel (T6) did not have any statistical differences between each other, while coconut powder (T3) promoted a lower result (Figure 3B). In relation to the germination speed, higher indexes were found for vermiculite and sand (Figure 3C).

There were statistical differences between treatments for mean germination time (Figure 3D). Seedlings growing in vermiculite had the lowest time, followed by blotting paper, paper towel, sand and Tropstrato substrate. Coconut powder did not present satisfactory results.

In relation to the shoot length, the highest seedlings development occurred when sowing the seeds on sand (T1), Tropstrato substrate (T4), coconut powder (T3) and vermiculite (T2), with no statistical difference among each other (Figure 4A). The substrates that promoted adequate seedling development, sand and vermiculite, probably offered the necessary conditions to a quickly and uniform germination, causing a suitable initial growth of Colubrina glandulosa, as mentioned by Nascimento et al. (2014).
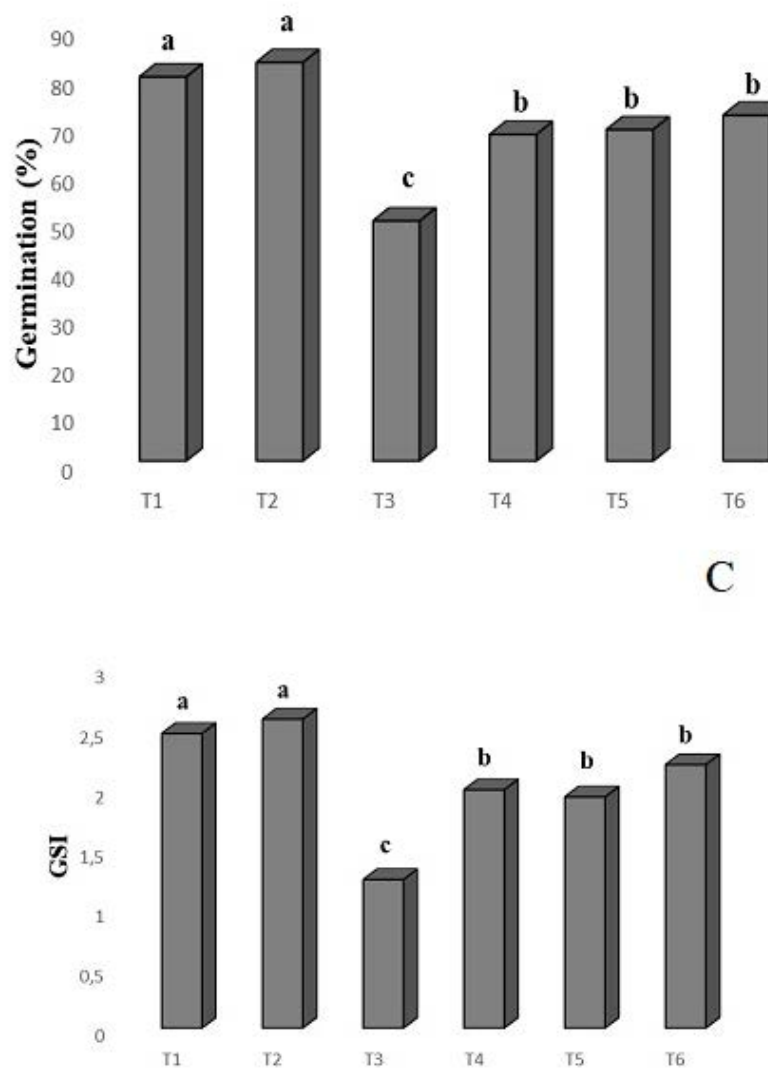
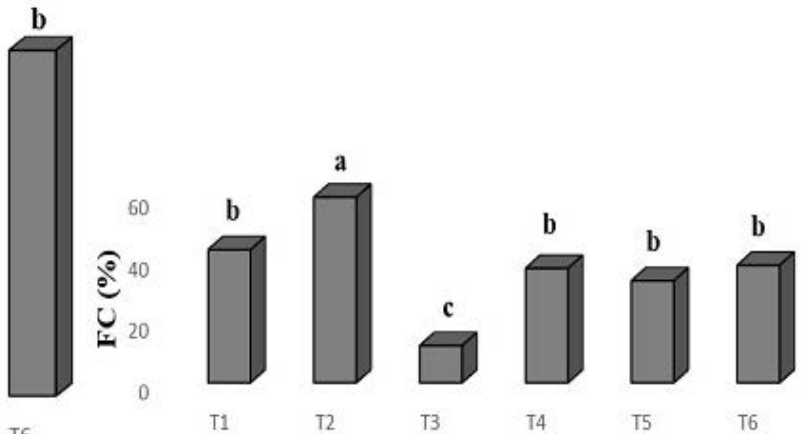

T6
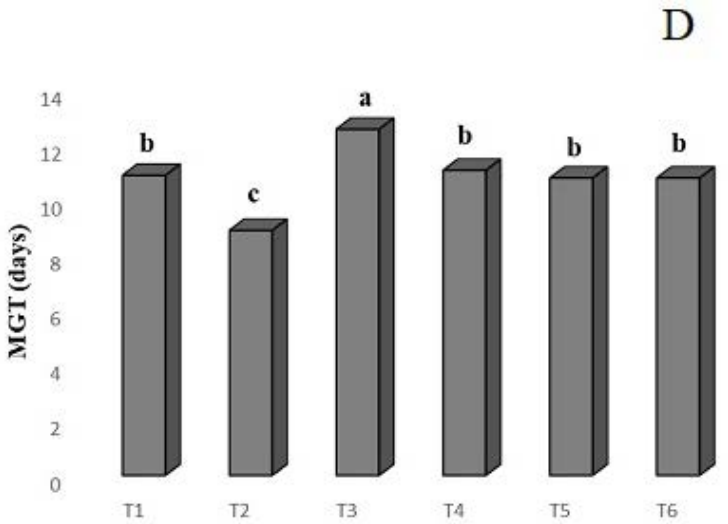

Figure 3. A- Means of germination ; B- first count (FC); C- germination speed index (GSI) and D- mean germination time (MGT) of Colubrina glandulosa Perkins seeds. CV=11.88\%, 26.02\%, $11.94 \%$ and 9.48\%, respectively. Treatments: T1 - sand; T2 - vermiculite; T3 coconut powder; T4 - Tropstrato; T5 - blotting paper; T6 - paper towel. 


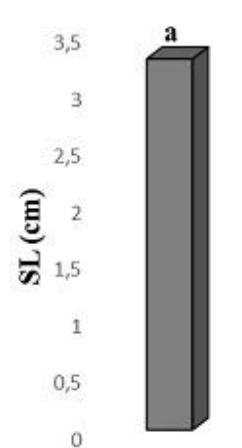

$\mathrm{T} 1$

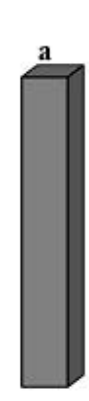

$\mathrm{T} 2$

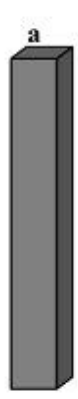

$\mathrm{T} 3$

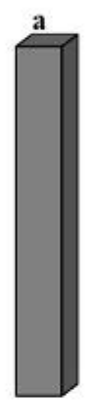

T4

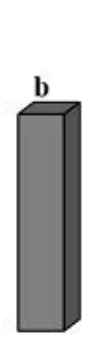

T5

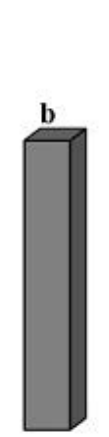

T6

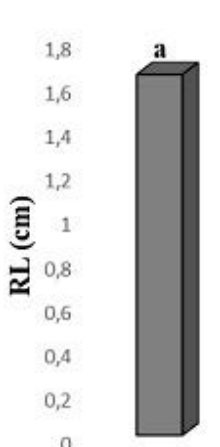

T1

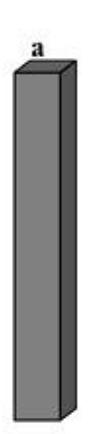

12

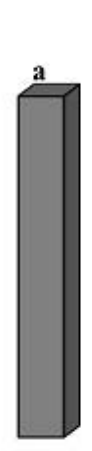

T3

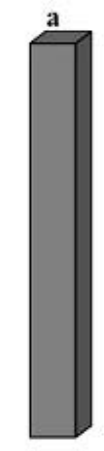

T4

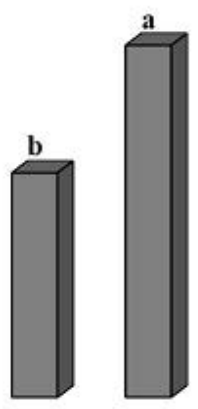

T6

C

D

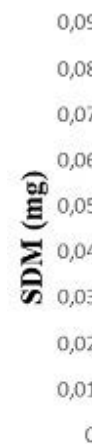

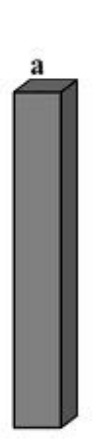

T1

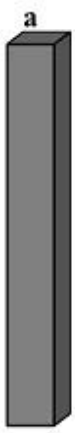

T2

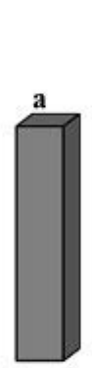

T3

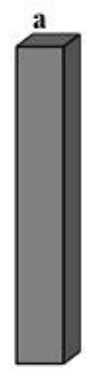

$\mathrm{T} 4$

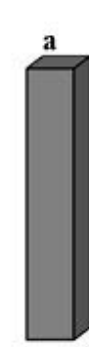

TS

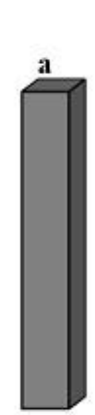

T6

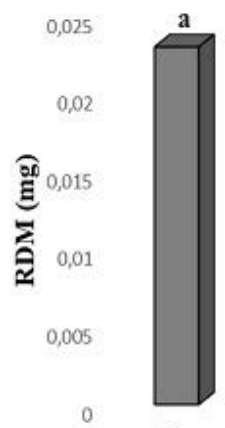

T1
T2

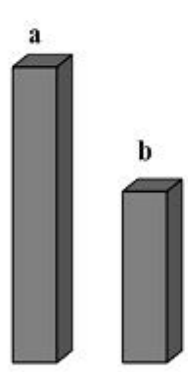

T3

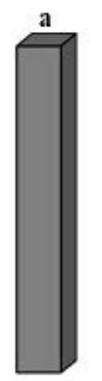

T4

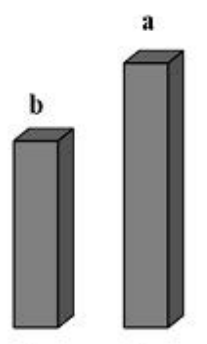

T5 T6

Figure 4. Means of A- shoot length (SL); B- root length (RL); C- shoot dry matter (SDM) and D- root dry matter (RDM) of Colubrina glandulosa Perkins seedlings sowed in different substrates. CV $=17.91 \%, 12.14 \%, 22.09 \%$ and $30.01 \%$, respectively. Treatments: T1 - sand; T2 - vermiculite; T3 - coconut powder; T4 - Tropstrato; T5 - blotting paper; T6 - paper towel.

As for the root length, only the blotting paper (T5) demonstrated statistical difference, having the lowest root system development (Figure 4B).

The different substrate types used for germination of Colubrina glandulosa seeds did not influence the shoot dry matter content, as there were no statistical differences between treatments (Figure 4C). Regarding the root dry matter, sand (T1) promoted higher results, as well as Tropstrato substrate (T4), vermiculite (T2) and paper towel (T6) (Figure 4D).

The results obtained for root dry matter in sand, vermiculite, Tropstrato substrate and paper towel were caused, probably, by the higher substrate aeration, with more efficient degradation of seed reserves (Guedes et al., 2010). The inferior results shown by blotting paper and coconut powder may have possibly occurred due to their physical properties, which were not compatible with the seed requirements on the water availability (Ferreira et al., 2008).

Germination, time, germination speed index and the seeds physiological quality are all influenced by the substrate used, and for this reason is essential studying its effects on the germination process (Abreu et al., 2017). A suitable substrate must promote higher seed germination, as well as favor seedling growth and development (Ferreira et al. 2008). In addition, it is also important mentioning that the substrate is very important for the water supply (Arantes et al., 2019). Therefore, according to the results obtained with the analyzed parameters, sand and vermiculite are the suggested substrates to be used for germination of Colubrina glandulosa seeds. Albuquerque et al. (1998) also concluded that sand and vermiculite are some of the more adequate substrates to be used in the germination of this species.

\subsection{Influence of the light on germination}

There was no difference between treatments on all variables analyzed. For this reason, Colubrina glandulosa may be classified as indifferent to light (Silva et al. 2014). Light-indifferent species may germinate under low concentrations of Fvd, the 
active form of phytochrome, a pigment responsible for the photoreaction. This may indicate that Fvd already exists in the seeds and may be related to the chlorophyll content of the extraembryonic tissue (Marcos Filho 2015).

The strong physical dormancy may also determine this condition. According to Azevedo (2015), many species from the Cerrado, one of the environments which C. glandulosa is found, are indifferent to light, due to the dormancy caused by their coat.

Although there was germination under light absence, almost all seedlings in this treatment presented yellowish or translucent hypocotyl and cotyledons, showing that chlorophyll synthesis did not occur, since production occurs when phytochromes are in their active form (Fvd). Hence, the seedlings presented a deficiency in their photosynthetic apparatus.

Results obtained for shoot and root length demonstrate that seedlings shoot and root system development of $C$. glandulosa may occur in a wide range of light conditions, contributing to the natural regeneration of this species.

The capacity of germinating regardless of the light quality is an essential adaptation of Colubrina glandulosa, as it ensures seed dispersion and colonization in areas with different environmental conditions (Ramos et al., 2020). Furthermore, from the ecological viewpoint, this is an important feature for it allows seedling development in environments with different successional stages (Holanda et al., 2015; Medeiros et al., 2019).

\section{CONCLUSIONS}

Temperatures of $20-30{ }^{\circ} \mathrm{C}$ and $30{ }^{\circ} \mathrm{C}$ are indicated for conducting experiments with Colubrina glandulosa Perkins, with immersion in sulfuric acid for 120 and 150 minutes. The necessity and efficiency of the chemical scarification method with sulfuric acid was proven for overcoming dormancy of C. glandulosa, which is caused by the coat impermeability.

Sand and vermiculite may be used for seedling production of C. glandulosa, as it offers ideal conditions for the species development. Light did not influence the germination of Colubrina glandulosa Perkins seeds, classifying the species as indifferent to light, demonstrating its establishment capacity in environments with different luminosities.

Colubrina glandulosa Perkins has high potential to be used in programs of recovering degraded areas, restoration and urban afforestation because this species can adapt to a wide range of environmental conditions.

\section{SUBMISSION STATUS}

Received: 30 June. 2020

Accepted: 13 October. 2020

Associate editor: Rodrigo Studart Corrêa (DD

\section{CORRESPONDENCE TO}

\section{Yana Souza Lopes}

Universidade Federal Rural de Pernambuco (UFRPE), Departamento de Ciência Florestal, Rua Dom Manuel de Medeiros, s/n, CEP 52171-900, Recife, PE, Brasil

e-mail: yanalopes0618@gmail.com,

\section{REFERENCES}

Abreu DCA, Porto KG, Nogueira AC. Métodos de superação da dormência e substratos para germinação de sementes de Tachigali vulgaris L.G. Silva \& H. C. Lima. Floresta e Ambiente 2017; 24 : e00071814.

Albuquerque MCF, Rodrigues TJD, Minohara L, Tebaldi ND, Silva LMM. Influência da temperatura e do substrato na germinação de sementes de saguaraji (Colubrina glandulosa Perk. - Rhamnaceae). Revista Brasileira de Sementes 1998; 20:346-349.

Almeida DS. Recuperação Ambiental Mata Atlântica. 3rd ed. IlhéusBahia: Editus, 2016.

Alves EU, Bruno RLA, Oliveira AP, Alves AU, Alves AU. Ácido sulfúrico na superação da dormência de unidades de dispersão de juazeiro (Zizyphus joazeiro Mart.). Revista Árvore 2006; 30(2):187-195.

Araújo AM, Assis LCSLC, Nogueira WN, Freitas RMO, Torres SB. Substrates and temperatures for the germination of seeds of Senegalia tenuifolia (L.) Britton \& Rose. Revista Caatinga 2016; 29(1):113-118.

Arantes CRA, Fava CLF, Camili EC, Scaramuza WLMP. Seed germination and seedling vigor of Magonia pubescens. Floresta e Ambiente 2019; 26(4): e20160467.

Azevedo IR, Paiva HN, Gomes JM. Efeitos de substrato, luz e temperature na germinação de sementes da espécie Buchenavia tomentosa Eichler (merindiba) em condições de laboratório. Agrienvironmental Sciences 2015; 1(1): 11-22.

Barbedo CJ, Santos Júnior NA. Sementes do Brasil: produção e tecnologia para espécies da flora brasileira. 1st ed. São Paulo: Instituto de Botânica, 2018.

Baskin CC, Baskin JM. Seeds: ecology, biogeography, and evolution of dormancy and germination. 2nd ed. San Diego: Academic Press, 2014.

Brancalion PHS, Mondo VHV, November ADL. Escarificação química para a superação da dormência de sementes de saguarajivermelho (Colubrina glandulosa Perk. - Rhamnaceae). Revista Árvore 2011; 35(1):119-124.

Brancalion PHS, Novembre ADLC, Rodrigues RR. Temperatura ótima de germinação de sementes de espécies arbóreas brasileiras. Revista Brasileira de Sementes 2010; 32(4): 015-021.

Brasil, Regra para Análise de Sementes, Ministério da Agricultura, Pecuária e Abastecimento. Secretaria de Defesa Agropecuária, Brasília: MAPA/ACS, 2009.

Bright RM, Davin E, O'Halloran T, Pongratz J, Zhao K, Cescatti A. Local temperature response to land cover and management change driven by non-radiative processes. Nature Climate Change 2017; 7:296-302.

Brito SF, Bezerra AME, Pereira DS. Efeito da temperatura e do KNO3 na germinação de Acnistus arborescens (Solanaceae). Floresta e Ambiente 2016; 23(3): 406-412.

Camara R, Fonseca Júnior AM, Sousa ACO, Pereira MG, Oliveira Júnior JQ. Influência do substrato e inoculação micorrízica na produção de mudas de Colubrina glandulosa Perkins. Floresta 2017; 47(4):449-458. 
Carvalheiro AL, Pimenta JA, Torezan JMD. Effect of some physical and chemical treatments on germination of Colubrina glandulosa seeds. Seed Science \& Technology 2007; 35:744-748.

wChin HF, Krishnapillay B, Stanwood PC. Seed moisture: recalcitrante vs. Orthodox seeds. Crop Science Society of America 1989; (14): 15-22.

Dousseau S, Alvarenga AA, Castro EM, Arantes LO, Nery FC. Superação de dormência em sementes de Zeyheria montana Mart. Ciência Agrotécnica 2007; 31(6):1744-1748.

Ferreira EGBS, Matos VP, Sena LHM, Sales AGFA. Germinação de sementes e desenvolvimento inicial de plântulas de crista-degalo em diferentes substratos. Scientia Agraria 2008; 9(2):241-244.

Flores J, González-Salvatierra C, Jurado E. Effect of light on seed germination and seedling shape of succulent species from Mexico. Journal of Plant Ecology 2016; 9(2): 174-179.

Garcia LC, Moraes RP, Sousa SGA. Superação de dormência em sementes de Colubrina (Colubrina glandulosa Perk.). Comunicado Técnico 80, Embrapa, Ministério da Agricultura, Pecuária e Abastecimento. Manaus; 2009.

Guedes RS, Alves EU, Gonçalves EP, Braga J, Viana JS, Colares PNQ. Substratos e temperaturas para testes de germinação e vigor de sementes de Amburana cearenses (Allemão) A.C. Smith. Revista Árvore 2010; 34(1):57-64.

Guedes RS, Alves EU, Santos-Moura SS, Costa EG, Melo PAFR. Tratamentos para superar a dormência de sementes de Cassia fistula L. Biotemas 2013; 26(4):11-22.

Holanda AER, Medeiros Filhos S, Diogo IJS. Influência da luz e da temperatura na germinação de sementes de sabiá (Mimosa caesalpiniifolia Benth. - Fabaceae). Gaia Scientia 2015; 9(1):22-27.

Houghton RA, Nassikas AA. Negative emissions from stopping deforestation and forest degradation, globally. Global Change Biology, 2018; 24:350-359.

Johnson CN, Balmford, A, Brook BW, Buettel MG, Guangchun L, Wilmshurt JM. Biodiversity losses and conservation responses in the Anthropocene. Science 2017; 356: 270-275.

Maguire JD. Speed of germination-aid in selection and evaluation for seedlings emergence and vigor. Crop Science 1962; 2(2):176-177.

Marcos Filho, J. Fisiologia de sementes de plantas cultivadas. 2nd ed. Londrina: ABRATES, 2015.

Martins CC, Bovi MLA, Spiering SH. Umedecimento do substrato na emergência e vigor de plântulas de pupunheira. Revista Brasileira de Fruticultura 2009; 31(1): 224-230.

Madeiros JX. Senna cana (Nees \& Mart.) H.S. Irwin \& Barneby: Morfologia de frutos, sementes, plântulas, plantas jovens e Ecofisiologia da germinação [tese]. Recife: Departamento de Ciência Florestal: Universidade Federal Rural de Pernambuco; 2019.

Medeiros JX, Feliciano ALP, Matos VP, Silva GH, Lopes YS, Ferreira RLC et al. Overcoming dormancy and influence of light on the physiological quality of Senna cana (Fabaceae). Journal of Experimental Agriculture International 2019; 34(5):1-9.

Melo LDFA, Melo Junior JLA, Ferreira VM, Araújo Neto JC, Neves MIRS. Biometric characterization and seed germination of giant mimosa (Mimosa bimucronata (DC) O. Kuntze). Australian Journal of Crop Science 2018; 12(01): 108-115.

Melo-Júnior JLA, Melo LDA, Araújo Neto JC, Ferreira VM. Germination and morphology of seeds and seedling of Colubrina glandulosa Perkins after overcoming dormancy. Australian Journal of Crop Science 2018; 12(4):639-647.
Morais Junior VTM, Jacovine LAG, Torres CMM, Alves EBBM, Paiva HN, Cruz RA et al. Early assessment of tree species with potential for carbono offset plantations in degraded área from the southeastern Brazil. Ecological Indicators 2018; 98:854-860.

Müller EM, Gibbert P, Binotto T, Kaiser DK, Bortolini MF. Maturação e dormência em sementes de Peltophorum dubium (Spreng) Taub. de diferentes árvores matrizes. Ilheringia 2016; 71(3): 222-229.

Nakagawa J. Teste de vigor baseados no desempenho das plântulas. In: FC Krzyzanowski, RD Vieira RD, JB França. Vigor de sementes: conceitos e testes. Londrina: ABRATES; 1999.

Nascimento IL, Maracaja PB, Silva MLS, Lima FM, Coelho DC. Emergência e crescimento inicial de plântulas de Caesalpinia ferrea Mart. ex Tul. var. leiostachya Benth. em diferentes tipos de solos. ACSA 2014; 10(2):42-49.

Oliveira AKM, Fernandes RM, Abreu CAA, Pina JC. Effect of different temperatures on the germination of Callisthene major (Vochysiaceae). Floresta e Ambiente 2020b; 27(1): e20170854.

Oliveira MFC, Silva WA, Silva CM, Santana JS, Silva A. Germination and initial seedling growth of Schizolobium amazonicum on different substrates and irrigation depths. Floresta e Ambiente 2020a; 27(1): e20171049.

Ramos MGC, Berto TS, Silva LG, Crisóstomo NMS, Melo LDFA, Melo Junior JLA et al. Efeito da luz e da temperatura na germinação de sementes de Mimosa bimucronata (DC) O. Kuntze. Revista Craibeira de Agroecologia 2020; 5(1): e9399.

Rodrigues Filho J, Corte VB, Perin ITAL. Dormancy breaking in Senna Pendula (Willd.) H. S. Irwin \& Barneby. Floresta e Ambiente 2019; 26(1): e20170002.

Rorato D, Araújo M, Dutra A, Turchetto F, Tabaldi L, Meith P. Seed analysis and seedling production of Matayba elaeagnoides Radlk. Floresta e Ambiente 2018; 25(2): e20160043.

Ruiz-Talonia L, Carr D, Smith R, Whalley RD, Reid N. Effect of temperature and light on germination of 10 species of Eucalyptus from north-western NSW. Australian Journal of Botany 2018; 66(8):657-666.

Santos LM, Farias SGG, Silva RB, Dias BAS, Silva LS. Ecophysiology of germination of Parkia platycephala Benth. seeds. Floresta e Ambiente 2019; 26(1): e20150282.

Smychniuk AA, Calvi GP, Ferraz IDK. Moist heat overcomes physical dormancy at the seed coat lens in Schizolobium parahyba var. amazonicum. Floresta e Ambiente 2020; 27(1): e20190093.

Silva KB, Alves EU, Oliveira ANP, Sousa NA, Aguiar VA. Influência da luz e temperatura na germinação de sementes de quixaba. Revista Agropecuária Técnica 2014; 35(1):13-22.

Silva JBC, Nakagawa J. Estudos de fórmulas para cálculo de germinação. Informativo ABRATES 1995; 5(1):62-73.

Silva LMM, Matos VP. Efeito da luz e da temperatura na germinação de sementes de coaçu (Triplaris surinamensis Cham.). Revista Brasileira de Engenharia Agrícola e Ambiental 1998; 2(1):94-96.

Silva KA, Martins SV, Miranda Neto, Campos WH. Semeadura direta com transposição de serapilheira como metodologia de restauração ecológica. Revista Árvore 2015; 39(5):811-820.

Walters C. Orthodoxy, recalcitrance and in-between: describing variation in seed storage characteristics using threshold responses to water loss. Planta 2015; 242(2):397-406. 